Portland State University

PDXScholar

1972

\title{
Selection of practice models for social work
}

Linda Fritz

Portland State University

Follow this and additional works at: https://pdxscholar.library.pdx.edu/open_access_etds

Part of the Social Welfare Commons, and the Social Work Commons

Let us know how access to this document benefits you.

\section{Recommended Citation}

Fritz, Linda, "Selection of practice models for social work" (1972). Dissertations and Theses. Paper 2147. https://doi.org/10.15760/etd.2145

This Thesis is brought to you for free and open access. It has been accepted for inclusion in Dissertations and Theses by an authorized administrator of PDXScholar. Please contact us if we can make this document more accessible: pdxscholar@pdx.edu. 


\title{
SELECTION OF
}

PRACTICE MODELS FOR SOCIAL WORK

\author{
Linda Fritz \\ Practicuum \\ Written Section for \\ School of Soclal Work
}

Committee

Dr. James Breedlove, School of Social Work Mrs. Phyllis Burnam; Family Counseling Service 
We do not know where we are going But we are on our way.

Stephen Vincent Benet

"Western Star" 
Introduction

The focus of my interest for a practicuum was soclal work methodology. When I first talked with Dr. Breedlove concerning my practicuum we agreed that I should do library research regarding social work as a problem orlented, as opposed to a procedure oriented, practice. My subsequent library work focused upon the question most fundamental to effective soclal work practice: How is the problem defined? What was the value position underlying the definition?

Numerous practice models exist within the profession of soclal work. No one can prove that one is more effective than another. If one model can demonstrate that it has a statistically higher success rate it is still unable to link cause with effect: it cannot show what it was in treatment that made the outcome better. One of the problems is that evaluative research has not proven to be an effective tool for the applied soclal sclences.. How could the researcher evaluate when nelther the problem nor the outcome have been minimally defined, much less operationalized? Even more basic to evaluative research is the definition of the underlying value assumptions. How, for example, was the decision made that the client was "improved" as a result of therapy? Whose relative definition of health/1liness was utilized? 
The position assumed in this paper is that whether a worker selects one practice model over another is baslcally a value question. There are some unique and diametrically opposed value positions assumed within the soclal sciences, and it is imperative that workers understand what these positions are so that they know where they are golng. Th1s paper will focus upon the value positions underlying two soclal work models: the traditional or psychodynamic and that of behavior modification. It is recognized that there are areas in which those twa approaches do not seem far removed, e.g., with some neo-behaviorists and/or some ego psychologists. However, to the extent that the Iines become very blurred, so does the clarity of position or practice. Ilke many practitioners who claim to be "eclectic," it becomes extremely difficult to find out where they are and what they do value at a given point in time. Why do soclal workers become so caught up in treatment facts? Because they have not clearly defined what they value and where those values lead them.

In order to demonstrate that the profession of social work has moved from position to position, this paper w1ll first sketch brlefly the early history of soclal casework. Second, the paper will focus upon some of the basic dangers involved in "borrowing" from the knowledge of other disc1plines. Finally, two major practice models, the traditional 
model and the behavior modification model w1ll be described both in terms of their nature and development and in terms of their conflictual value positions. Social workers need to be cautious not only to ldentify the values from which they are operating, but also to be certain that their positions are not too narrow or simplistic for the effective dealing with life. 


\section{A Brief History of Soclal Work Practice}

Grace Coyle once noted that, "Soclal work has always been dominated by two factors: the soclal climate in which It moves and the state of the sclences on which it is dependent."I This being true some thirty years hence, it is necessary to understand not only the soclal work literature, but the zeltgeist which has continued to alter the emphasis and direction of soclal work effort.

Early in the twentieth century soclal work, influenced both philosophically by pragmatism and socially and politically by the Progressive era, was in what has been termed the sociological stage: a stage which centered upon the conviction that man's life experience was environmentally determined. Pragmatism drew away from the Puritan bellef that man's problems were due to moral inadequacy and toward the recognition that many of man's problems could be traced to his environment. "Reform the environment in the service of the individual was the battle cry. The method proposed was the use of the soclal sclences, especially soclology."2 Thus social workers directed their efforts at

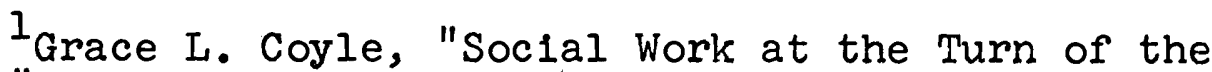
Decade," Proceedings of the National Conference of Soclal Work $(1940)$, p. 12 .

${ }^{2}$ Nathan Edward Cohen, Social Work in the American Tradition (New York: Holt, Rinehart \& Winston, 1958). p. 314.
} 
modification of the milieu. Such intervention included things like child placement, neighborhood houses, separating individuals within families, and changing jobs. 3

Th1s, then, was the social climate of the early nineteen hundreds, but the other factor was of equal 1mport: the state of the sciences. Newton was, and continues to be, the theoretical glant; and social work was optimistic that the key to prevention and cure would lie in such scientific laws and methods. 4 Not only were soclal workers in need of a scientific knowledge base for their profession, but there was also the omnipresent bellef that science would cure all soclal 1lis and lead to unlimited progress. Exemplary of this belief was the development of the Charity Organization Socleties, in the $1870^{\prime} \mathrm{s}$, for the purpose of making charity, or almsgiving, scientific and efficient.

In 1889 a paper entitled "Scientific Charity" by Mrs. Glendower Evans (National Conference of Charities and Corrections Proceedings 1889:24) likened the appl1cation of sclence to charity to the use of a physician in 1ilness, urging that the same intelligence and scientific spirit which created power over the physical world be used to understand and modify social forces. 5

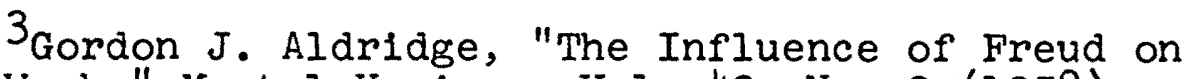
Soclal Work," Mental Hyglene, Vol. 42, No. 2 (1958), pp. 284-288.

${ }^{4}$ Carel Germain, "Casework \& Sclence: A Historlcal Encounter," in Theorles of Soclal Casework, ed. by Robert W. Roberts, Robert H. Nee (Chicago: The University of Chicago Press, 1970), p. 8.

I Ib1d. 
Mary Richmond: Soclal Diagnosis

It was with Mary Richmond's publication of Soclal Diagnosis in 1917 that the foundation was la1d for a scientific approach to casework. 6 Soclal diagnosis was comprised of the definition of the social situation and the personality of the client. This diagnosis, arrived at by a process of collecting and evaluating information and drawing Inferences, was concelved of as a procedure common to all casework. Miss Richmond, writing in the perlod described above as "soclological," stressed the situational aspects of the case: the history gathering was emphasized with the bellef that if enough facts were collected the problem's solution would be forthcoming. There were two key concepts to M1ss Richmond's philosophy: that there were differences between and among Individuals, and that man is a product of his social relationships. 7 Social work's basic aim, from Mary Richmond's perspective was the development of personal1ty. Casework consisted "of those processes which develop

6 Charlotte Towle, "Soclal Casework," Social Work Yearbook (New York: Russell Sage Foundation, 1947) in Carel Germain, Ibid., p. 9.

7 Irma Stein (unpublished paper, New York School of, Soc1al Work, in Cohen, op. c1t., pp. 131-132. 
personality through adjustments consciously effected, individual by individual, between men and their social environment." 8

At the time when Miss Richmond was writing, soclal work was beginning to feel the impact of psychiatry. Albeit Freudian theory was not yet dominant, Richmond did lean heavily on the "social psychiatric" writings of Adolph Meyer of Johns Hopkins University. ${ }^{9}$ It is notable that in 1911 Dr. Meyer read a paper on "Case Work in Soclal Service and Medical and Social Cooperation in Nervous and Mental Diseases."IO Also in some cities,

- . psychiatrists were members of case conferences, and contributed not only to the method of understanding clients, but also to the education of the professional staff. The influence had been only rarely felt before the war; but after 1918 it became essentlal for anyone practicing in the field of soclal casework to understand the dynamic functions of the emotions. II

Influenced by psychiatry, soclal work was then concurrently influenced by medicine. Mary Richmond, for example, not only quoted frequently from Wllliam Osler, the

8Mary E. Richmond, What is Social Casework? (New York: Russell Sage Foundation, 1922), p. 98.

9Barbu Valer, review of "The Commonsense Psychiatry of Adolph Meyer," in American Journal of Psychoanalys1s, $1950, \mathrm{p} .71$; V. Meyer and Edward S. Chesser, Behavior Therapy in Clinical Psychlatry (New York: Sclence House, Inc., 1970), p. 14; Frank J. Bruno, Trends in Soc1al Work $1874-1956$ (New York: Columbia University Press, 1957), pp. 187, 284.

$$
\begin{aligned}
& 10_{\text {Bruno, op }} \cdot \frac{\text { c1t., p. } 183 .}{\text { Ib1d., p. } 187 .}
\end{aligned}
$$


famous Johns Hopkins surgeon, but two of her closest advisors were prominent physiclans.

It seems reasonable to suppose that these many associations contributed to her development of the medical or disease metaphor of soclal diagnosis and treatment. It was during the Baltimore years that she wrote, for example, of pauperism as "a disease" and of the friendly visitor as a "social" physician or general practitioner of charity who is called upon to "heal" complex conditions. 12

Th1s medical, or disease model, was one by which the Individual's behavior was consldered pecullar, abnormal or diseased, because of some underlying cause; the analogy being made, of course, to medicine in which lesions, germs, viruses and other insults foreign to the normal working of the organisms lead to symptom production. 13

Psychiatric influence was not as apparent in Soclal Diagnosis, which gave equal time to the "Inner" and "outer" factors affecting personality development, as it was in

12 Murlel Pumphrey, "Mary Richmond and the Rise of Professional Soclal Work in Baltimore," DSW dissertation, Columbla University School of Soclal Work, University Microfilms Publication \#17,076, Ann Arbor, Michigan, in Germain, op. c1t., pp. 12-13.

13Leonard P. Ullman and Leonard Krasner, Case Studies In Behavior Modification (New York: Holt, Rinehart and Winston, 1965), p. 12; L. B. Thorpe and B. Katz, The Psychology of Abnormal Behavior (New York: Ronald, 1948), pp. 161-162, 166; N. A. Cameron, Personal1ty Development and Psychopathology (Boston: Houghton Mifflin Company, 1963), p. 452; A. P. Noyes and L. C. Kolb, Modern Clinical Psychiatry, 5th ed. (Philadelphia: Saunder, 1958), p. 96. 
other social work realms. Three outstanding attempts were made prior to the $1930^{\prime}$ 's to establish a generic base for casework. The first was Mary Richmond's Social Diagnosis The second was the paper presented by Mary Jarrett at the National Conference of Soclal Work in 1919 entitled, "The Psychlatric Thread Running Through All Social Case Work." The third was the emphasis in the 1929 Milford Conference Report which tended to limit casework to "the adjustment of the deviant individual to his environment."14 Thus soclal casework which had been accused by Abraham Flexner in 1915 of having no transmissible knowledge and skill of its own was embracing the new developments of psychlatry: a medical model, and with it, a study-diagnosis-treatment framework. ${ }^{15}$

\section{Soclal Factors}

Many soclal factors were operating in favor of adoption of the psychlatric model. Workers in medical settings seeking professional status were anxious to differentiate themselves from nurses and other staff; by 1dentifying with the higher status profession of medicine, with the physiclan's body of knowledge and his method of diagnosis and

${ }^{14}$ Cohen, op. c1t., p. 140.

15 Harold L. W1lensky and Charles N. Lebeaux, Industrial Society and Social Welfare (New York: The Free Press, 1958), p. 177 . 
treatment, social work status was enhanced. 16 During this same period mental health settings were recelving the impact of the mental hyglene movement. Clifford Beer's book, A Mind That Found Itself, gave strong 1mpetus to the already burgeoning interest in the individual qua individual.

With the opening of Smith College's training school for psychlatric social workers, social work both responded to the need for trained workers to handle the emotional problems of returning World War I veterans and relatives, and it established precedent for a psychiatric training model. The following notice of opening appeared:

On July 8, 1918, Smith College and the Boston Psychopathic Hospital, under the auspices of the National Committee of Mental Health, will open at Smith College a training school for psychiatric soclal workers to assist in the rehabilitation of soldiers suffering from shell-shock and other nervous disorders. ${ }^{17}$

This announcement marked the culmination of the dream of Miss Mary Jarrett and Dr. Ernest Southard to establish "a profession school which would emphasize the importance of soclal work in the practice of psychlatry . . ."18

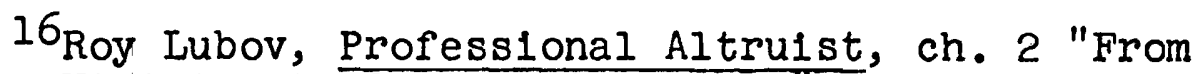
Friendly Visiting to Soc1al Diagnosis, "in Germain, op. c1t., p. 13 .

17El1zabeth L. Grover, "H1story and Philosophy of Social Welfare, 1918-1932" (unpublished paper, New York School of Soclal Work, April 1956, in Cohen, op. c1t., pp. $132-133$.

${ }^{18}$ Cohen, op. c1t., p. 133. 
During World War I, soclal workers were not only responding to the emotional needs of veterans, but to the increasing interest of psychiatry, psychology and b1ology in the psychological aspects of human behavior. Typical of this interest in the United States was the "home service divisions" of the American Red Cross. Because of the war shortages of psychlatrists, soclal workers, supervised by psychlatrists, were given substantial responsibility in the treatment of psychoneurotic patients.

Following World War I the nation turned within 1tself. It refused to accept the growing interdependence of the world and instead turned to isolationism. Concurrent w1th the end of the war was the demise of the Progressive era, and the national concern for soclal reform. Soclal reform, for social workers, was both out of fashion, and often politically dangerous; therefore soclal work turned to working more intensively with the individual and to sharpening its technical skill. 19

In summary, soclal work shifted, to use Porter Lee's terms, from a preoccupation with "cause" to a preoccupation with "function." It must be born in mind that this turn

19E. Pumpian-Mindin, "The Position of Psychoanalysis in Relation to the Biological and Soclal Sclences, "In Psychoanalysis as Sclence (Stanford: Stanford University Press, 1952), pp. 133-134, in Cohen, op. c1t., pp. 317-319. 
Inward was not unique to soclal work. The post war twenties brought a "culturewide interest in the unique inner world of Individual experience. ${ }^{2}$ Important is the fact that social work practice reflected the spirit of the times.

The Impact of Freud

S1gmund Freud offered to soclal work a behavioral theory which accounted for all the data of human behavior, 1ts development, and 1ts pathological deviations. Albeit Freud was formulating a specific, while general, theory he remained in contact with the concrete detalls of Iife so that his general set of postulates and assumptions had high applicab1lity.

Freud's theoretical relationship to the so-called medical model is straightforward. His first training was in medicine: physlology. The following account taken from Freud's major professor's lecture briefly describes his educational orlentation:

Physlology is the sclence of organisms as such. Organisms differ from dead material entities in action-machines in possessing the faculty of assimilation, but they are all phenomena of the physical world; systems of atoms, moved by forces, according to the princlple of the conservation of energy discovered by Robert Mayer in 1842, neglected for 20 years, and then popularized by Helmholtz. 21

20 Germain, op. c1t., p. 16.
$21_{E}$. Jones, The Iife and Work of Sigmund Freud, Vol. I (New York: Basic Books, 1953), pp. 41-45. 
Jones went on to say:

It has often been assumed that Freud's psychological theorles date from his contact with Charcot or Breuer or even later. On the contrary, it can be shown that the principles on which he constructed his theorles were those he had acquired as a medical student under Brucke's influence. 22

Most important for soclal work practice was not Freud's metapsychology, but the insights which he provided regarding the nature of man: Soclal influence in early iffe is most important because the basic personality structure is laid down during the first six years of 11fe. Man is mot1vated by his instincts (IIfe and death) and is continually engaged in working with his instinctual conflicts; therefore, all behavior is not rational because it is rooted in the irrational emotions. Much behavior is not conscious and is therefore not amenable to "direct" influence.

Therapy based upon Freudian insight adheres to the basic 1dea that motives dictate behavior. This means, for one thing, that disordered behavior is the result of pecullarities inside the individual. 23 Following the medical

${ }^{22}$ Ib1d.; Gregory Z11boorg and George W. Henry, A History of Medical Psychology (New York: W. W. Norton and Co., 1941), in Herbert Bisno, The Philosophy of Soclal Work, (Washington, D.C.: Public Affairs Press, 1952), p. 87.

23 Gordon $J$. Aldridge, "The Influence of Freud on Social Work," Mental Hyglene, Vol. 42, No. 2 (1958), pp. 284-288. 
model, the therapist must seek out the inner states that underlie the surface difficulties and by bringing them to light, loosen the bond between them and the disordered behavior they produce; the therapist attempts to lead the patient to some "Insight" regarding the relationship between his motivations and his behavior. 24 Insight means understanding: if the client understands the basis of his behavior, then that behavior is more meaningful. The client, gaining insight, is not only freed from disabling symptoms, but his life is made more meaningful. Perry London described the technic of "Insight therapy" as,

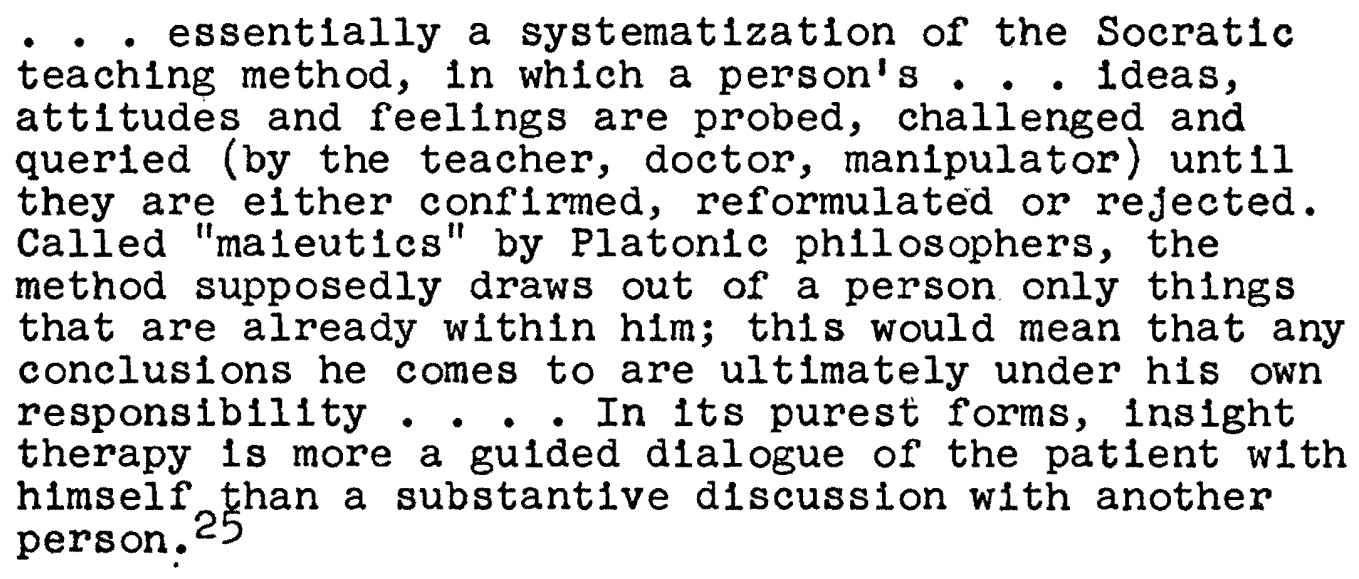

Psychoanalytic theory, therefore, of fered rich insights, and a kind of treatment technique which met the needs of a profession seeking methods oriented to individ-

$24 \mathrm{~J}$. C. Coleman, Abnormal Psychology and Modern Iife, 2nd edition (Chicago: Scott, Foresman, 1956), p. 225. 25 Perry London, Behavior Control (New York: Harper and Row, 1969), pp. 58-59. 
ualized service. 26 The selection of Freudian theory was not without difficulties. Psychoanalysts, for example, had to undergo extensive training in order to acquire their skill, whereas social workers applying the same insights often launched into such difficult areas of interpretation without the necessary knowledge of underlying thoughts and feelings. However, as a direct result of the impact of Freudian psychoanalysis in the 1920's and 1930's diagnostic soclal work theory was formulated and taught by the faculty of such leading schools as the New York School of Soclal Work, the University of Chicago School of Social Service Administration, and Smith College School of Soclal Work. 27

Social casework has incorporated and taught from many assumptions derived from Freudian theory. Caseworkers usually work from the assumption that maladaptive behavior is a surface symptom of an underly1ng emotional disorder. 28 Also the importance of family relationship in

26 Germain, op. c1t., p. 10 .

27 Ruth E. Smalley, "The Functional Approach to Casework Practice," in Theories of Soclal Casework, ed. by Robert W. Roberts, Robert H. Nee (Chicago: The University of Chicago Press, 1970), p. 83.

28 Max Bruck, "Behavior Modification Theory and Practice: A Critical Review," Soclal Work, Vol. 13, No. 2 (April 1968), p. 39; Florence Holl1s,". . And What Shall We Teach? The Soc1al Work Educator and Knowledge," Soc1al Service Review 42 (June 1968) pp. 184-96. 
the development of the individual, especially during the earliest years, has been accepted by social work pract1tioners: 29

All social workers must recognize that the family as a unit of interacting personalities is the primary institution in the formation of personality and character. 30

Social work's individualizing emphasis in casework was derived as much from psychoanalytic thought as from democratic-Judeo-Christian ideas. 31 Freidlander states that:

Caseworkers must be able to use skillfully the knowledge of human behavior in stressful situations. Such knowledge is to be found in psychological theories on the structure, development and functioning of the ego and 1ts manifest expressions in the personality. 32

or to quote other soclal work literature:

Along with this recognition of the complexity of human motivation there is an understanding of the purposive and symptomatic nature of overt behavior.

${ }^{29}$ Virginia Robinson, A Changing Psychology in Soclal Case Work (Chapel Hill, North Carolina: University of North Carolina Press, 1930), p. 34 .

30 Helen I. Clarke, Principles and Practice of Social Work (New York: D. Appleton Century Company, Inc., 1947) p. 420.

${ }^{31}$ Germain, op. c1t., p. 18.

32 Walter A. Friedlander, Concepts and Methods of Soclal Work (Englewood Cliffs, New Jersey: Prentice-Hall, Inc.), p. 21 . 
In other words overt behavior is the result of certain "needs" which motivate 1t; the behavior is the "symptom" of these "causes." 33

Numerous other examples could easily be drawn from the 11terature, but suffice it to say that Freudian theory has had, and continues to have, a profound impact upon the social work profession.

What is Generic Social Work?

The position taken in this paper agrees with Alfred Kahn's statement that, "The unifying conceptual key to all soclal work method has not yet been identified... . 34 To cite an instance, because psychoanalytic concepts have been so extensively incorporated into soclal work a great deal of the professional literature has concerned itself with differentiating the function of the psychlatrist and the soclal worker. Iuclile Austin states that cases sultable for casework are those in which the client is able to focus upon social adjustment and relationships; client's needing to deal with psychological content would be treated via psychotherapy. 35 Judd Marmor disagrees with Miss Austin. He

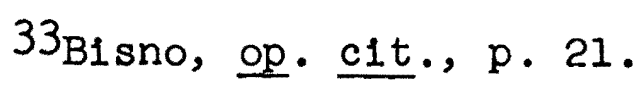

34 Alfred J. Kahn, ed., "The Function of Social Work in the Modern World," Issues in American Social Work (New York: Columbia University Press, 1959), p. 7 . ${ }^{35}$ Lucille N. Austin, "Relationships Betweenn Family Agencies and Mental Health Clinics," Social Casework (1955) $36: 51-59$. 
states that her distinctions are not valid and that "both approaches must consider intrapsychic as well as social factors." 36

The current trend within soclal work, and the one upon which behavior therapy has capitalized, is more consistent with Miss Austin's position than it is with Marmor's. Soclal work, in an attempt to establish a unique identity, has turned to a more pronounced focus in the traditional role of the soclal worker as the expert in all social aspects. 37 Justin Simon adheres to this emphasis in his pronouncement that the essence of soclal work is in the word "social" and 1ts complex ramifications. 38

Soclal Work Values: What Are They?

Numerous authors have dealt with the subject of social work values. 39 However, the basic issue of the under-

36 Judd Marmor, "Indications for psychiatric therapy. or social casework," Social Casework (1955) 36:60-63.

37 Alfred Kadushin, "The Knowledge Base of Social Work," in Alfred Kahn, ed., Issues in American Social Work (New York: Columbia University Press, 1959), pp. 63-64.

${ }^{38}$ Justin Simon, "Toward a Psychoanalytic Definition of Soc1al Casework," Social Service Review (1962) 36:1-12.

${ }^{39}$ Smalley, op. c1t., p. 12l; Friedlander, op. c1t., pp. 2-6; Florence Hollis, Casework, A Psychosocial Therapy (New York: Random House, 1965), p. 12; Bisno, op. c1t., pp. 10-11; Sw1thun Bowers, OMI, "The Nature and Definition of Social Casework," Journal of Soc1al Casework (1940). 
lying importance of professional values has been given scant attention. 40 According to casework-critic Elizabeth Salomon (1967), the casework process has two fundamental parts, the personal intultive and empathic and the scientific. She says that although it is difficult in our culture, the caseworker must have an increased consclousness that the two parts intersect in the professional relationship. Miss Salomon described the two philosophical positions as that of positivism (the philosophical system dealing only with positive facts and phenomena, rejecting abstract speculation) and humanism (any system of thought or action principally or exclusively concerned with human interests and values).

Some workers within the profession feel that if there is a conflict between the scientific, or positivistic, values and humanitarian values, that the humanitarian values would be the ones to be discarded. ${ }^{41}$ If, in fact, this is how the conflict is resolved, social work may shift from 1 ts

40Th1s paper is following Kluckhohn's definition of value, 1951, p. 395, as "a conception, explicit or implicit, distinctive of an individual or characteristic of a group, of the desirable, which influences the selection from available modes, means and ends of action."

${ }^{41}$ Barbara Varley, "Soclal Work Values: Changes in Value Commitments of Students from Admission to M.S.W. Graduation," Journal of Education for Soclal Work, Vol. 4, No. 2 (Fall 1968), pp. 67-76. 
primary humanitarian values of the dignity and the right of each individual to full development of his capacities, the interdependence of individuals and their consequent respons1bility toward each other in the framework of their capac1ties. For according to the positivistic point of view:

With its credo of a new enlightenment, its cult of objectivity and its empirical methodology--the currency of the world of Freud and Richmond--the world is discoverable and knowable. Its scientific method, induction, consists of breaking down natural objects into their characteristic elements and then elaborating these elements into types--or concepts, judgments, conclusions and theorles. Most significant, the inductive method of positivism holds that a real world can be observed and that the observer can be divorced from what he observes. 42

There is considerable agreement that the general

values held by the social work profession are unclear, if

indeed they are existent. Ernest F. Witte stated that:

The corroding influence of the materialistic society in which social work is practiced appears: to change the behavior and values of social workers and make their response more nearly like that of the general public despite professed goals which would suggest a different pattern. 43

\footnotetext{
42 Elizabeth L. Salomon, "Humanistic Values and Social Casework," Social Casework, Vol. XIVIII No. I (January 1967) p. 27 .

43 Ernest F. Witte, "Student Wisdom and Values: The Positive Force of Disaffection," Soclal Work Values in an Age of Discontent, ed. by Katherine A. Kendall, New York Council on Soc1al Work (1970), p. 95.
} 
Ruby B. Parnell concurs with Mr. Witte:

American social work, both as an expression and instrument of American social and moral values, is inextricably tied up with what America is at any one period of time and this tends to reflect the major concerns of the era. We have moved as the times demanded or permitted from a commitment to charity, to a commitment to justice, to a commitment to science . . . Compassion, social justice and disciplined knowledge are all part of our armamentarium, though we fall short in all three. 44

The main implication of this confusion regarding professional values is that individual workers do not determine their diverse value selections by standards of their profession, but by such things as their cultural and family background, the precepts and demands of a given group, their own personal experlence, and/or in terms of some soclal:sclentific theory regarding human behavior.

The positivist might well argue that the issue of values is of little import: after all the therapist can be objective. However, numerous studies have demonstrated that the observer cannot be divorced from what he observes. Behaviorists might argue for their "objectivity" on the ground that they are able to make decisions, to diagnose and formulate treatment plans, without ever being subjectively

${ }^{44}$ Ruby B. Pernell, "Soclal Work Values on the New Frontiers," Soclal Work Values in an A.ge of Discontent, ed. by Katherine A. Kendall, New York, Council on Soclal Work Ed. (1970), p. 51. 
involved. It must be pointed out that their "objective theory," their princlples and concepts, have been validated only because they have been seen as "good" via subjective judgments of a number of peers. Further, treatment is always directed toward a goal which has been judged as "good" by someone. Usually the therapist is the one who determines the goal as being one of "better social adaptation" or the like. Does not the judgment of what behavior is "adaptive" necessarily 1mply a value judgment? Adaptive In terms of middle class ethics, democracy, in terms of the continuation of the social "status quo," Individual happiness, mankind, survival, development of the species, art and creativity, encouragement of genius or of mediocrity and conformity?

The therapist does not work independently of an assumed value position. Casework is a social situation in which therapist and client respond in a system of mutual Influence. Goldsteln (1962) has brought together considerable literature on this area. He demonstrated that expectations have an important effect upon how other's behavior will be evaluated, and upon which behavior will be manifest. For example, there is an interdependence of the client's expectations of help and the likelihood of his being helped. Also, the theraplst may be influenced by how well he likes the subject. Self-fulfilling prophecy is frequently at work: 
The therapist who evaluates the subject as a poor risk for therapy will be less likely to establish good rapport, which will increase the chances of fallure, and validate his original belief that the person was a poor bet. Knowledge about soclal class, and intellectual and verbal abilities may all make the patient more desirable for therapy and lead $\mathrm{hIm}$ to be assigned to a more capable therapist. 45

Regardless of how the theraplst's values are acquired, the worker does train the patient to emit certain selected "correct" responses. Marmor has described the results of this process:

But what is insight? To a Freudian it means one thing, to a Jungian another, and to a Rankian, a Horney1te, and Adlerian, or a Sullivanian, still another. Each school gives its own particular brand of insight. Who shall say whose are the correct insights? The fact is that patients treated by analysts of all these schools may not only respond favorably, but also belleve strongly in the insights that they have been given. Even admittediy "Inexact" interpretations have been noted to be of therapeutic value. Moreover, the problem is even more complicated than this for, depending upon the point of view of the analyst, the patients of each school seem to bring up precisely the kind of phenomenological data which confirm the theorles and interpretations of their analyst. Thus, each theory tends to be self-validating. 46

Values are, therefore, baslc to practice. Soclal work must be more than an art based upon intuition. It must be

${ }^{45}$ Leonard P. Ullman and Leonard Krasner, Case Studies In Behavior Modification (New York: Holt, Rinehart and Winston, 1965), p. 37 .

46 Judd Marmor, "Psychoanalyt1c Therapy as an Educational Process" (Paper presented at Academy of Psychoanalys1s, Chicago, May, 1961, in J. H. Masserman, ed. Psychoanalyt1c Education (New York: Grune and Stratton, 1962). 
based upon values and principles and an organized, eclectic body of knowledge. Because soclal work values have not been firmly established, soclal work's claim to professional status is suspect. Etzioni points out in his book The SemiProfessions that because social work falled to distinguish itself as a profession, it has become a mere society of technicians. Etzioni states that social work practice is not determined, as is the medical practice, by professional standards or values, or by the patient's problem, but by the policy of the agency in which the social worker is employed. Soclal workers are best described as agents of their particular system. Unfortunately, the question of the social worker's identity can best be addressed if we first know something of the individual worker's personal background and values, his soclal sclentific preference and the agency in which he works.

Should Soclal Work Borrow Knowledge From the Soclal Sclences?

There is hardly one national or state conference that does not today have an appreciable segment of its program devoted to consideration of the relationship of social sclence theory and research to social work practice. Inst1tutes and workshops with soclal science themes and social science participants are proliferating, schools of social work are increasingly more cognizant of this content in master's as well as doctoral programs, and our journals reflect similar growing awareness. It is pertinent to note also that trends within the field of psychiatry have had some effect on soclal work in this regard, as in so many others. It might be falr to say that an even more intensive interaction with the social 
sciences has developed within psychiatry than within social work. There is no escaping the conclusion that the soclal sciences are with us, and we cannot look to psychiatry as a haven against these new winds that are blowing our way. They are blowing just as strongly within psychiatry. One may note, as illustrations, several recent works that reflect the growing collaboration between psychiatrists and social sclentists....

The relevance of social science to social work may no longer be questioned. What is important is how we prepare ourselves to be selective and judiclous about what we choose to accept, how we choose to integrate and apply what we accept, and what we ourselves decide to test. 47

Albeit it is acknowledged that social work is still a long way from having "a scientifically tested and validated practice theory," social work is attempting to improve its scientific approach with the use of the physical and the soclal sciences. 48 However, as the previous section pointed out, social work's historlcal emphasis upon goals, which are derived from certain fundamental values, presents difficulties for the researcher. When the worker applies scientific knowledge he is necessarily involved not only in "what is" but also in what "should be." Even social sclentists are

47 Herman D. Stein, "The Concept of the Social Environment in Social Work Practice," in Ego-orlented Casework: Problems and Perspectives, ed. by Howard J. Parad and Roger R. Miller, Family Service Association of America, New York (1963), pp. 65-66.

${ }^{48}$ S. Z. Hasan, "Concepts and Methods in Soc1al Work Research," in Cora Kasius, ed. New Direction in Soclal Work (New York: Harper, 1954). 
becoming cognizant of the fact that "nelther the body of knowledge, nor the activities of its seekers, is morally neutral."49 In addition social workers must seek to ut1lize scientific knowledge to pursue humanitarian goals.

However, social scientific knowledge has been helpful to the social worker, and can continue to be. Applied soclal sclence may help soclal work, for example, to create both descriptive and prescriptive diagnostic principles and a typology of understanding of what types of problems can be handled at various levels of practice. Social science also could ald in developing a closer approximation of a concept of non-pathological processes and a fuller appreciation of man's potent1al1ties. 50

Inherent in these contributions are dangers. Because of the time lag in the interdisciplinary movement, soctal workers are likely to borrow yesterday's knowledge. Also workers are likely "to endow borrowed knowledge with a greater degree of certainty than. is granted it by the disci-

\footnotetext{
${ }^{49}$ Cohen, op. c1t., p. 291.

50 James L. Breedlove, "Some Implications of Social
} Sclence for Soc1al Work" (unpublished paper, Aprll 1960). 
pline which originaliy developed this knowledge."51 Mr. Kadushin cites as exemplary the fact that although there are 257 definitions of the word "culture" in the literature, social work continues to use the word as though there were only one possible meaning. Next, soclal workers "are likely to borrow a simplified version of the truth, and one falsified to the degree that it is simplified."52 In his article "Inquiry and Policy: The Relation of Knowledge to Action," Max Millikan addressed himself to the fallacy of scientists who maintain that they can predict complex social behavior. This is fallaclous because science is by definition atom1stic--1t must separate and isolate parts of the whole in order to analyze and study the phenomenon in question. Once something is isolated from the whole, from its social context, it most often becomes a completely different phenomenon. If, for example, it was initially a social phenomenon it no longer has anything with which to interact, and thus can be examined only as a static rather than a dynamic. Millikan expresses that "after the materlal has been separated from its context it is then reduced to its lowest

${ }^{51}$ Alfred Kadushin, "The Knowledge Base of Social Work" in Issues in American Social Work, Alfred Kahn, ed. (New York: Columbia University Press, 1957), p. 67. 52 Ibid, p. 68. 
terms."53 The danger of "simplification" follows for generalizations which stem from soclal sclence theory and research; it must be remembered that they remain general1zations. 54 There is the added danger of "confusion of identifications which seems to be the result of interprofesslonal borrowing." 55

Helen Harris Perlman 56 states that part of the problem in the use of soclal sclence theory is not in the theory but in social work itself:

Our difficulty is our overwhelming sense of needfulness--the feeling that somehow we have falled to find the keys that unlock the right doors to human behavior. This combines with the hope that someone else holds these keys. Once we thought soclology held them; then we thought psychoanalytic theory held them; now we seem to think soclal sclence holds them. We are not even sure what soclal science consists of, what combined bodies of knowledge are 1ts constituents and whether all of these: bodies can claim the rubric "science." But we reach out avidly, eager to know better in order to do better.

The caveat we must hold before ourselves is against letting the need blind us, "Words seem to hold magic, and the use of words like "communication" and "transaction" and "cllent system" and "role network" may infuse us with a heady sense of having something to concur with. We can weave word-spells around one another, but unless we plumb these words for their particular meaning, for what phenomena. they express, and then for what their implications for action are, we will find

53Max F. Millikan, "Inquiry and Policy: The Relation of Knowledge to Action," in The Human Meaning of the Soclal Sclences, ed. by Daniel Lerner (1959), pp. 158-182.

${ }^{54}$ Stein, "Concept of Social Environment," p. 67. 55 Kadushin, op. c1t., p. 68.

56 Helen Harris Perlman, "Social Work Method: A

Review of the Past Decade," in The Practice of Soclal Work, ed. by Robert W. Klenk and Robert M. Ryan (Belmont, California: Wadsworth Publishing Co., Inc.), pp. 57-75. 
ourselves disappointed again that what we thought was gold is dross. Something of this sort has begun to happen in work on family diagnosis. It somehow does not quite tell us what to do about family treatment. 57

The final danger is that borrowed material will remain in an "undigested lump: interesting but unintegrated and unused." 58 There has been no systematic attempt on the part of the soclal work profession to validate social scientific knowledge. "A seemingly truthful, self-evident hypothesis achieves the status of fact by sheer repetition - . ."59 For example, there is a general acceptance in the literature of the hypothesis that the client demonstrates high negative ambivalence when applying for financlal assistance. However, research gives a much firmer reason to belleve that this hypothesis is true for some client groups but not for others. 60

Kadushin describes that although social work has some systematized high-level abstractions regarding the worker's approach to the client, concepts such as acceptance, non-Judgemental attitude, and self-determination, and

$$
\begin{aligned}
& 57_{\text {Ibid., p. } 7 .} \\
& 58_{\text {Kadushin, op. c1t., p. } 69 .} \\
& 59_{\text {Ibid., p. } 48 .} \\
& 60_{\text {Ivor Svarc, "Client Att1tudes Toward Financial }}
\end{aligned}
$$
Assistance--A Cultural Variant," Social Service Review XXX (1956) pp. 136-146, in Kadushin, op. c1t. 
some broad treatment typologies, such as soclal therapy, supportive treatment and insight therapy, there is an essential difference between the high-level abstraction of selfdetermination, for example, and the actual face-to-face application of this concept in treatment. Kadushin contrasts the difference "between knowledge based on experlence and casual observation as against knowledge formulated on the basis of rigorous, critical, systematic examination."61 Essentially, "there is a gap in the identification and systematic validation of our knowledge." 62

It must be kept foremost in the worker's msnd that the primary value of soclal science content is its relevance to practice. 63 And if soclal work is to borrow, then the "test of relevance should be applied within the function and competence of the soclal work practitioner. 64 Applied knowledge must be put to a pragmatic test. Is the theory useful to social work? Does it offer a better explanation for the material in question? Does it suggest new and better solutions for problems? These questions do not inquire

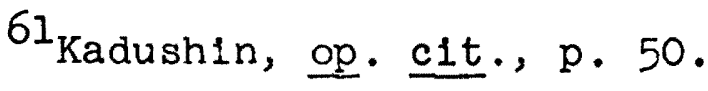
62 Ib1d., p. 51 .

${ }^{63}$ Stein, "Concept of Soclal Environment," p. 66. ${ }^{64}$ Ib1d., p. 67.
} 
of the theory's valldity, but they do test the applicability of the theory to the field of soctal work. ${ }^{65}$ In order to borrow effectively from the social sclences, soclal work needs first to examine the client's needs, and then to undertake applied research designed to convert social scientific theory into principles of practice. One of the first tasks to be accomplished in such research is an analysis of the value implications: to clarify soclal work goals in relation to cultural and/or social scientific values.

Behavior Therapy as Reactive to Traditional, Psychodynamic Therapy

Essentially behavior modification was a therapeutic approach developed in reaction to the so-called dynamic school. Earlier in the paper a case was made for the strong heritage which social work has acquired from this "dynamic" school. Therefore, it would at first glance appear that the "behavior modification" or "learning theory" approach might be in contradiction with some of the underlying assumption of soclal work. In order to assess the therapeutic relevance, however, it is necessary to examine first what principles of dynamic psychology the behavior-

${ }^{65}$ Selma Fraiberg, "Psychoanalysis and the Education of Caseworkers," in Ego-Orlented Casework: Problems and Perspectives, ed. by Howard J. Parad and Roger R. Miller (New York: Family Service Association of America, 1963), pp. 236-258. 
Ists were reacting to; second, the assumptions upon which they based their reaction; third, how, in fact, they did react: what was the nature of the "contradictory" practice theory?

Behaviorists take issue with five basic tenets of psychodynamic theory. Like the medical disease model, the psychodynamic model incorporated the assumption that maladaptive behavior was simply a surface symptom of an underlying emotional disorder, and that any direct attempt to modify such behavior must fall or result in substitution of other symptoms. 66 Coleman is very explicit in his adherence to the traditional or dynamic viewpolnt:

Psychological treatment . . focuses on (1) helping the patient to understand the dynamic significance of h1s symptoms--how they came about and why he uses them, and (2) helping him to strengthen his personality and find more adequate and effective means of dealing with his problems...

The first major obstacle is the resistance of the patient to being cured. What the neurotic really wants is to be cured of his symptoms without having to face h1s problems or to give up the more or less unconsclous satisfactions which the symptoms obtain for him. Thus he frequently insists on discussing his symptoms at great length, seemingly in a sincere attempt to help the theraplst get a clear view of them....

66 Bruck, op. c1t., p. 39; Florence Hollis, "...And What Shall We Teach? The Social Work Educator and Knowledge," Soclal Service Review 42 (June 1968), pp. 195. 
In some cases the patient's symptoms may temporar1ly disappear so that he is convinced it is unnecessary to return for further treatment. For this reason the immediate disappearance of symptoms is often looked upon as a poor prognostic sign. In still other cases the symptoms may seemingly become intensified and the patient may report that he is becoming worse and has declded to consult another therapist. Thus, it is often very difficult to overcome the patient's resistance to the actual facing of his problems; yet this is required in any effective therapy.

A common pitfall in therapy is the treatment of symptoms rather than underlying personality difficulties... unless the underlying personality conflicts are properly handled by psychotherapy the same neurotic symptoms or others designed to defend the patient from his problems will soon appear. 67

Behaviorists state that Coleman's notion of not treating the symptom directly ignores the patient's reason for coming to therapy. Eysenck, a behaviorist, reports that, "there is no neurosis underlying the symptom but merely the symptom itself. Get rid of the symptom and you have eliminated the neurosis." 68 Ullmann and Krasner argue that,

It seems falrer to use one's scientific and professional knowledge to help the patient achieve "his" goal than it is to draw him into a process, even if it is called self-actualization which the patfent did not request and which is not firmly validated. 69

67 Coleman, op. cit., p. 225. $68_{\mathrm{H}}$. J. Eysenck, "Learning Theory and Behavior Therapy, "Journal of Mental Sclence (1959), in Leonard P. Ul Iman and Leonard Krasner, Case Studies, pp. 61-75. 69 Ullman and Krasner, Case Studies, pp. 40-41. 
Behavior modifiers continue to point out that ilterature dealing with the question of whether or not insight is a sufficient condition for change in actions is replete with negative instances. 70

Second, the behavior therapists point to the weakness in psychodynamic theory of development: it is essentially a conflict theory which assumes that all development, normal and neurotic, stems from the conflicting demands of 1d, ego, and superego. Whlle neurot1c structures may be formed through these conflicts, normal structures are not and theis development must be explained in any adequate theory of development. Contrariwise, the behavior modification people utilize a varlety of learning principles like reward and punishment to account for all behavior. For the behaviorist all behavior, normal and pathological, is learned behavior, and is therefore dependent for 1ts existence upon past and present reinforcement principles. As B. F. Skinner maintained--what is learned is what gets reinforced by the individual's reinforcing community. The basic construct for behavioral psychology is expressed by the equation $B=f(s)$ which means that behavior is some function of the

70 D. D. Cahoon, "Symptom Subst1tution and Behavior Therapies: A Reappraisal," Psychological Bullet1n 69 (March 1968), pp. 149-56. 
stimulus. Stimulus comes, in this case, from the external environment; for even if there were recognizable stimuli from inside the individual they would be discounted by the behaviorist, because they would not be avallable for assessment by the objective observer. All behavior is defined as e1ther respondent, that behavior which is controlled by the preceding stimulation, or operant, those responses controlled by consequent stimulation.

In addition to not being effective in the area of symptom alleviation, the behaviorists argue that the psychodynamic therapies are extremely restrictive in their definition of the client population. Traditionally, attention was directed to the individual, his motivation and his verbal skill so that the institutional or social inadequacies were obscured. Further, this approach was often less effective with clients having problems that were soclally percelved rather than self-percelved. ${ }^{71}$ Problemmatic were the facts that those whose personal or cultural characteristics did not coincide with the model tended to be excluded, and that the exclusive focus upon the individual process all but ignored the social context in which the person and the problem were embedded. ${ }^{72}$ Behaviorists, in opposition,

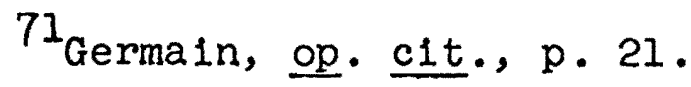
72 Ibid, p. 15 .
} 
direct all of their attention to the environment: to that which is external to the organism. Further, they do not eliminate clients on the basis of their verbal accessibility, or their capacity for introspection. Rather, they group clients into problem areas, some of which they claim greater success than others, attempt to systematically discover the way in which the "symptomatic" behavior is being reinforced, and treat by altering the system of reinforcement. They maintain that all behavior is learned in this way, and therefore no client is necessarily excluded from therapy. Following the medical, or disease model, the psychodynamic theorles were based upon the idea that the client was in some way deficient. Further, the model led to the categorization of clients in terms of presumed underlying 1IInesses. The behaviorists argue that the psychodynamic nosology were developed on a descriptive basis and as a result of social and historical pressures, and that therefore they were only products of medical soclology rather than groups based upon the validation of clearly defined diseases or definite patterns of behavior. 73 Behaviorists again maintain that they avoid such "social and historical" pressures: they do not have an elaborate nosology; rather

73Uliman and Krasner, op. c1t., p. 9 
they look carefully at the symptomatic behavior, what precedes and follows the behavior, and upon the basis of such information establish treatment. 74 According to Hilgard:

The working behavior theraplst is $11 k e l y$ to ask three questions: (a) what behavior is maladaptive, that is, what subject behaviors should be increased or decreased; (b) what environmental contingencies currently support the subject's behavior either to maintain his undesirable behavior or to reduce the likelihood of his performing a more adaptive response; and (c) what environmental changes, usually reinforcing stimuli, may be manipulated to alter the subject's behavior.75

Finally is the issue alluded to above: psychodynamic terms are badly defined; in fact, operational definitions are almost entirely lacking. The dynamic focus upon thoughts and feelings makes dynamic theory relatively inaccessible to research methodology. The verbatim records, case studies, of psychotherapy are naturalistic records. Such records are important for one phase of the development of science and have the invaluable function of bringing the scientific observer a reasonably complete view of the real-1ife situation that he is encountering. However, naturalistic records are hard to analyze and, because of the inability to carry out experimental controls, they

74 William R. Morrow and Harvey L. Gochros, "Misconceptions Regarding Behavior Modification," Soclal Service Review Vol. 44 No. 3 (September 1970), p. 293.

75 E. R. Hilgard, Introduction to Psychology 3 rd ed. (New York: Harcourt, 1962), p. 614. 
are difficult to use as a basis for the actual confirmation or disconfirmation of a theory. Also language of the dynamic clinicians has been demonstrated to have very low rellability, and to bear little relationship to the ensuing treatment. ${ }^{76}$ In contrast, behaviorists claim to use no terms, diagnostic categories nor treatment processes which cannot be defined operationally: in phenomenological terms. Behaviorism, in many ways, was more of a philosophical position than a sclentific method. 77 Essentially the behaviorists combined logical positivism in philosophy and operationism in physics to human behavior. Concepts, such as mental constructs and processes, which could not be subjected to empirical study were rejected. B. F. Skinner explained that:

.. "mind" and "ideas" are non-existent entities, invented for the sole purpose of providing spurious explanations ... Since mental or psychic events are asserted to lack the dimensions of physical sclencer, we have an additional reason for rejecting
them.78

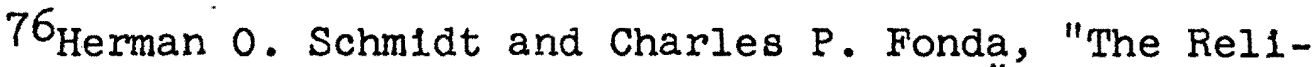
ability of Psychiatric Diagnosis: A New Look," in Herbert C. Quay, ed. Research in Psychopathology (Princeton, New Jersey: D. Van Nostrand Co., 1963; Frederick H. Kanfer and George Saslow, "Behavioral Diagnosis," in Cyr1l Franks, ed. Assessment and Status of Behavior Theraples and Assoclated Developments (New York: McGraw H1ll Book Co., 1970).

77 Charles A. Catania, Contemporary Research in Operant Behavior (Glenview, IIIInols: Scott, Foresman and Company, 1968), p. 1 .

78 B. F. Skinner, Sclence and Human Behaviour (New

York: Macmilian, 1953), pp. 30-31. 
Behavior of the Individual was to be manipulated and measured in a controlled laboratory situation. Explanation of behavior was couched in positivistic assumptions such as the atomistic nature of the whole and linear causality. In explanation, the behaviorists proposed to understand all of human behavior by first understanding simple behaviors and then combining a number of simple behaviors. Further the behaviorists operational assumptions that behavior occurs lawfully, so that any human problem could be vlewed as part of a chain of cause-and-effect relationships, led to the consequent 1dea that the amelioration of problems can and should be planned. Belng operationally defined and based upon such emplrical behavior principles as the law of operant reinforcement and the law of extinction, behaviorists clalmed to have an empirically validated practice theory. 79

In summation, behavior modification is a practice theory based upon social sclentiflc learning theorles. H. J. Eysenck, for example, defined behavior therapy as "the attempt to alter human behavior and emotion in a beneficial

$79_{\mathrm{H}}$. J. Eysenck, Experiments in Behaviour Therapy (New York: The Macmlilan Company, 1964), pp. 40-51; Gordon Paul, Insight vs. Desensitization: An Experiment in Anxiety Reduction (Stanford: Stanford University Press 1966); Gordon Paul, "Insight vs. Desensitization in Psychotherapy Two Years After Termination, "Journal of Consulting Psychology 31 (August 1967), pp. 33-48. 
manner according to the laws of modern learning theory." 80 The behaviorists assume that all behavior is learned, and is therefore under the control of stimuli from the exterior environment. In terms of learning theory, there is no such thing as pathological behavior that is separate from normal behavior: normal and abnormal behavior are considered continuous. Influenced by the cultural relativism of anthropology, the behavior therapist assumes the position that behavior is "abnormal" only if it is inappropriate for the environment in which it occurs. If it suits the cultural or subcultural norm, it is adaptive; if not, it is maladaptive. The cause of abnormal behavior is the particular history of reinforcement of each individual.

of import is the fact that there is not one modern learning theory.

The point is that psychologists engaged in behavior modification make use of a variety of learning theories, but their actual operations can be described with ease by any one of a number of learning theorles. ${ }^{81}$

$80_{\mathrm{H}}$. J. Eysenck, "The Nature of Behaviour Therapy," in Experiments in Behaviour Therapy (New York: The Macmillan Company, 1964), p. I.

${ }^{8} 1_{\text {Ullmann }}$ and Krasner, Case Studies, p. 16. 
For example, behaviorists working with chlldren or hospitalIzed clients usually apply terms derived from B. F. Skinner's work, while workers dealing with adult sexual or neurotic problems more often ut1lize terms and concepts derlved from the work of Guthrie. 82

These theories were formulated as a result of exper1mental data collected on cats, plgeons, rats, and monkeys. Following Darwin's notion that there is blological continuity among organisms of similar structure, the principles developed from laboratory experiments with animals were applied to humans. 83 Because these applications met with some success, it was subsequently assumed that human behavior followed basically the same laws as did animal behavior.

Behavior therapy practice follows from the philosophical assumptions of logical positivism. In all methods, the client's responses are carefully observed before therapy begins, and the therapeutic plan is then designed specifically to meet the client's specific need. Very briefly there are four basic types of behavior therapy now prac-

\footnotetext{
82Bruck, op. c1t., p. 48; I. Breger and J. L. McGaugh, "Critique and Reformulation of 'Learning Theory' Approaches to Psychotherapy and Neurosis," Psychological Bulletin (1965) $63: 340-343$.

${ }^{83}$ Catania, op. c1t., p. 2.
} 
ticed. The first, and by far the most prevalent within soclal work, is called operant conditioning. Based upon the postulate that all behavior is controlled by 1 ts consequences, it exists not only as an independent method, but also presupposes all other kinds of behavior modification. Looking at operant conditioning in terms of a formula:

$S \rightarrow R \rightarrow R^{+}$is the designation meaning that a stimulus elicits a response which must be positively relnforced in order for a response to continue or increase in frequency. The therapeutic technique, thus, is one of manipulating the rewarding or punishing content of environmental stimuli, and is utilized with children having severe behavioral problems, autistic chlldren, self-help skills and increased contact with environment in psychotics and retardates; conversion reactions, enuresis and speech disorders.

Second, a subtype of "operant conditioning," is "aversive therapy" or "counter-conditioning." In counterconditioning an aversive stimulus is presented simultaneously with a maladaptive response in order to extinguish, or weaken it, or an aversive stimulus is removed in order to negatively reinforce a desirable response which has a low frequency. In some situations, extinction is accompanied by the withdrawal of a positive stimulus after a maladaptive response. This method has been used in treating alcoholism and sexual disorders. 
The method of "negative practice" has also been utilized in extinguishing maladaptive responses by repeatedly eliciting them in the presence of neutral or reinforcing circumstances. For example, it has been assumed by behaviorists that "neurotic" behavior was learned because of anxiety-producing conditions in the environment. Thus, if the response is frequently emitted when these conditions are removed, the "neurotic" response should disappear. Behavior modification literature describes this technique as applicable to problem areas such as stuttering, tics, sexual disorders, and obsessive compulsive reactions. Finaliy, there is the method of "systematic desens1tization." Based upon Hull's principle of reciprocal inh1bition and upon Skinner's development of behavioral shaping by successive approximations, this process begins with the construction of a hierarchy of anxiety-producing stimuli. The patient is placed, next, in a state of extreme relaxation, and stimuli of gradually increased anxlety content are then introduced. Fundamental to desensitization is the postulate that no human being is capable of entertaining two antagonistic feelings simultaneously; that 1s, one cannot feel anxious and relaxed at the same time. In theory, the relaxed state of the organism is incompatible with an anxiety state, consequently the inappropriate maladaptive 
responses are ext1ngulshed. 84 Desensitization is the treatment cholce for phoblas of all types. It has also been used with conversion reactions, anxiety reactions, impotence and frigidity, voyeurism, exhibitionism and stuttering.

\section{Critique of Behavior Modification}

Negative reactions to behaviorists have been diverse and numerous. This paper, however, w111 only sketch out three broad categories of criticism. First is the area of behaviorism's assumed value position. The purely sociological "environmentalism" of learning theory has raised a number of questions as to the nature of man, and the extent to which he can or cannot be determined entirely by his milieu. Von Bertalanffy argued that,

If you manipulate a dog according to Pavlov, a cat according to Thorndike, or a rat according to Skinner, you will obtain the results described by these authors. That is, you select, out of their behavioral repertolre, such responses as may be controlled by punishment or reward, you "make" the animals into stimulus-response machines or robots. The same, of course, is true of humans .. - However, in so doing, you de-rattisize rats and dehumanize humans. . .

Psychology in the past fifty years was a fight against what has been called the "anthropomorphic fallacy," that is, imputing to animals human sentiments

${ }^{84} \mathrm{Joseph}$ Wolpe and Arnold A. Lazarus, Behavior Therapy Techniques (Oxford: Pergamon Press, 1966). 
and capabilities. But it was forgotten that there equally is a "zoomorphic fallacy" canceling any difference between animal and man. 85

Erich Fromm expresses his discontent in another direction:

Therapy almed at nothing but soclal adjustment can only reduce the excessive suffering of the neurotic to that average level of suffering inherent in conformity to these patterns . . . The "adjusted" person in the sense in which I have used the term here is one who has made himself into a commodity, with nothing stable or definite except $h 1 s$ need to please and $h 1 s$ readiness to change roles. As long as he succeeds in his efforts he enjoys a certain amount of security, but his betrayal of the higher self, of human values, leaves an inner emptiness and insecurlty which will become manifest when anything goes wrong in his battle for success.

In a sense the behaviorist assumes the position of a technician. The client's presenting problem is "fixed" by the therapist; however, the client is in no way helped to be more capable of dealing with the next problem which arises. Essentially the painful symptom may be alleviated, but the client is not helped toward growth; toward understanding, for example, how he developed the symptom inftially. There are no value positions, says the behaviorist; all values are relative to the culture. Of course if values are relative to the culture, then they must be relative to the subculture within that culture, next they must be relative to

${ }^{85}$ Ludwig Von Bertalanffy, Robots, Men and Minds (New York: George Braz1ller, 1967), pp. 13-15. 86 Erich Fromm, Psychoanalysis and Religion (New Haven: Yale University Press, 1950). 
the groups and sub-groups within the sub-culture, and finally they must be relative to the individual. For the behaviorist, theoretically then, there could be no shared values. Von Bertalanffy exchanges the word "meaning" for "values":

of course, in "verbal behavior" (Skinner, 1957) within a linguistically full-grown soclety the conventional pattern of operant behavior and reinforcement plays a large role. Nevertheless, as Chomsky (1959) has emphasized in his critique of Skinner's book, learning by "meaning" or "understanding" is essentialiy different from and cannot be reduced to reinforcement. In Skinner's scheme, there is no place for a sentence's being "true" (i.e., corresponding in some way t.o "fact"); one sentence is as good as the other, presupposing it is sufficlently reinforced. This, also, is correct for manipulating psychology, the conditioning of the human animal through mores, ingrained metaphysics and preJudices, mass media and the like. It leaves completely unexplained that there is something like a search for "objective truth" (independent of and frequently contradicting reinforcement and animal gratification), that there is "meaning" beyond conditioned response to word stimuli, that the latter form grammatical patterns accordIng to laws of symbolic systems . . .

Academic psychologists have difficulty dealing with a number of things which would seem to be rather essential to deal with: In a theory regarding human behavior. They cannot, for example, speak of ethical reality; they have no way to account for efforts at self-comprehension; there is no way, so to speak, for behaviorists to hold their man together:

87 Bertalanffy, 오. c1t., pp. 26-27. 
for example, where does the individual store his "history of reinforcement"; how and when does 1 t become pertinent to the present? They cannot account for the wholeness of a person apart from the part process; neither can they deal with growth and change within a context of an enduring identity; finally, there is no explanation for the concreteness of an individual's own special experience. There is little question that behavior modification techniques have proven successful in the alleviation of many symptoms, and in Von Bertalanffy's terms that human can be made into robots, but do we have to follow the direction of an eminent American scientist who stated that, "We must go to the moon, for the simple reason that we can do $1 t^{\prime ?} 88$

If social workers were to subscribe to behavior therapy as a practice theory there would be value 1mplications. First, if it were assumed that man was solely a product of his environment, then the diagnostic process could have only one direction: to understand a particular individual, the worker need only understand the environmental forces upon him. Second, principles such as "self-determination" would have to be discarded for not only does the therapist assume complete charge of the process, but egalitarlanism

\footnotetext{
${ }^{88}$ Rene Dubos, "Second Edition: Does Man Have a Future," The Center Magazine Vol. IV No. 2 (March/April 1971), p. 57 .
} 
reigns: Individual differences are simply a result of the environment. Finally, social work therapy would consist entirely of social action: if the worker would improve the man, he must first improve his milieu.

A second group of criticisms centers around the behaviorist claim of being "scientific." Behavior modifiers claim to have "operationalized" their terms, but what, for example, is the operational definition for "reinforcement"? Is reinforcement a concept or a tautology? It is appropriate here to recall Perlman's warning that words seem to hold magic; workers cannot allow themselves to be blinded by words. Is the behaviorist operational definition of human behavior satisfactory for social workers? Finally, are the behaviorists capable of being as "objective" as they maintain? Can they remain truly separate from their subJects? Danlel Yankelovich and W1lliam Barrett answer these questions in the negative:

There is no reality to be measured independently of the measuring apparatus. If, now, one thinks of the measuring apparatus as a means of perception, then we may say that the lesson of modern physics is the subject (perceiving apparatus) and object (the reality measured)

${ }^{89}$ Daniel Yankelovich and W1lliam Barret, Ego and Instinct: The Psychoanalytic View of Human Nature Revised (New York: Random House, 1970), p. 203. 
Carl Rogers questions that anyone can "object1vely" know anything:

Thus, if a physicist says that he "knows" that the speed of a freely falling object is expressed by the formula, $v=32 t$, what he means is that various individuals, whom he trusts have each gone through similar operations, which can be precisely described, and have observed similar results; and each has arrived at a similar subjective conviction, which is expressed in the formula, which is understood in a similar manner by all. The physlcist believes the convictions are similar because he has exercised his own empathic ability in understanding the communications and the internal frame of reference of others. 90

Finally, the question must be asked, does behavior modification offer better explanations for the material in question, or are the answers merely more simplistic and therefore more easliy digested? A number of practice theories have unfortunately followed Wittgensteln's log $1 \mathrm{c}$ when he stated, "Woven man nicht sprechen leann, clarüber muss man nicht schweigen" (Whereof one cannot speak, thereof one must be sllent). How are practitioners to grow if the unanswered questions are not clearly stated, and someone does not attempt their resolution? Finally, regarding behavior therapy, soclal workers might do well to remember Cohen's warning :

90 T. W. Wann, ed., Behav1orism and Phenomenology (Ch1cago: University of Chicago, 1964), p. 113. 
Social work, with the help of the soclal scientists, must continue to seek ways of enriching 1ts own knowledge and skills from this source. In so dolng, however, it must avoid the danger of mere substitution of sociology for psychology.91

\section{Nature/Nurture: An "Old Debate?}

Ostensibly, behaviorism amounted only to a denial of the doctrine of innate 1deas: that man has an "essence" of "Inner nature" which remains unaffected by the vicissitudes of sensory experience. In actuality, however, behaviorism's argument with the "traditional" approach was an offshoot of a much deeper issue--"the perennial question of nature versus nurture." 92 Another way which this debate can be described is through the paradoxes of practice outlined by Halmos in his book, The Faith of the Counsellors. 93

Basically Halmos explicated upon six paradoxes which he felt were inherent in the therapeutic process: At the same time that the therapist was to utilize scrupulously thought out strategies, he was to act and react with spontaneous lovingness. The client was dealt with as though motivated by supreme rationality and intelligence and/or

$$
\begin{aligned}
& { }^{91} \text { Cohen, op. c1t., p. } 332 . \\
& 92_{\text {Richard Lowry, The Evolution of Psychological }}
\end{aligned}
$$
Theory (New York: Aldine-Atterton, Inc., 1971), pp. 54-55. $93 \mathrm{P}$. Halmos, The Faith of the Counsellors (New York: Schocken, ig66). 
he was impulsively or emotionally motivated. Therapists were told to "be-in-charge" at the same time that they were being non-directive. The therapeutic act was viewed simultaneously as an act of caring or helping and an application of sclence. Therapists were forced to deal with the paradox of whether their client learned by didactic teaching or Insight. Finally, the worker was taught that the process had a beginning, middle and end concurrently with the idea that there was an interminable nature to the therapeutic relationship.

Behaviorists, in their reaction to psychoanalytic thought, basically pointed out that the dynamic model had addressed itself primarliy to only one side of each of Halmos' paradoxes. In effect the behaviorists have only assumed the other side of each pair. Behaviorism concentrates upon what the client does; behavior modification is completely planned around the establishment of an S-R bond; 94 the therapist is "In charge" of the process;95 emotionality is an unwanted and unnecessary intervening varlable; the process has a beginning, middle and end; and the process is entirely empirical; it is a direct applica-

94 Ullmann and Krasner, Case Studies, p. 36.

95 Morrow and Gochros, op. c1t., p. 302; Wolpe and Lazarus, op. cit., p. 17. 
tion of sclence. 96 The very fact that these theorles have Iimited themselves in this manner has made each of them inadequate practice theorles.

Each tries to be simultaneously comprehensive and rigorous, treating everything and explalning everything. Neither alm is achieved very well because the extremes of each position reflect an oversimplifled view of human behavior; translated into the clinical area, this oversimplification requires psychotherapists to be continuously ready to cheat on their systems or on their intellects if they want to work verry well and explain to themselves what they are doing. 97

96 Ullmann and Krasner, Case Studies, p. 37.

97 Perry London, Behavior Control (New York: Harper and Row, 1969), p. 56 . 


\section{BIBLIOGRAPHY}

Aldridge, Gordon J. "The Influence of Freud on Soclal Work." Mental Hygiene, Vol. 42, No. 2 (1958), 284-288.

Austin, Lucille N. "Relationships Between Family Agencies and Mental Health Clinics." Soclal Casework (1955), $36: 51-59$.

Bandura, Albert. Princlples of Behavior Modiflcation. New York: Holt, Rinehart \& Winston, Inc., 1969.

"Psychotherapy as a Learning Process." Psychological Bulletin, 58:2 (1961) 143-159.

Beck, Aaron T. "Cognitive Therapy: Nature and Relation to Behavior Therapy." Behavior Therapy. Edited by Cyr11 M. Franks. Vol. 1 (May 1970, 205-212.

Bereleman, William C. "Mary Richmond's Soclal Diagnosis in Retrospect." Soclal Casework, Vol. XIIX, No. 7 (1968), 395-402.

Bisno, Herbert. The Philosophy of Soclal Work. Washington, D.C.: Public Affairs Press, 1952.

Bloom, Martin. "Connecting Formal Behavioral Science Theory to Individual Social Work Practice." The Soclal Service Review, Vol. XXXIX, No. 1, 11-22.

Borenzwe1g, Herman. "Soclal Work and Psychoanalyt1c Theory: A Historical Analysis." Soclal Work, Vol.16, No. 1 (1971), 7-16.

Bowers, Swithun, O.M.I. "The Nature and Definition of Social Casework." Journal of Soclal Casework (1940).

Breedlove, James L. "Some Implications of Social Sclence for Social Work." Unpublished paper, April 1960.

Breger, L. and J. L. McGaugh. "Critique and Reformulation of 'Learning Theory' Approaches to Psychotherapy and Neurosis." Psychological Bulletin, 63:338-358 (1965). 
- "Learning Theory and Behavior Therapy: A Reply to Dachman and Eysenck." Psychological Bulletin (1966) 65:170-173.

Bruck, Max. "Behavior Modification Theory and Practice: A Critical Review." Social Work, Vol. 13, No. 2 (1968), 43-55.

Bruno, Frank J. Trends in Soc1al Work 1874-1956. New York: Columbia University Press, 1957.

Cahoon, D. D. "Symptom Substitution and Behavior Therapies: A Reappraisal." Psycholog1cal Bulletin (1968) $69: 149-56$.

Cameron, N. A. Personality Development and Psychopathology. Boston: Houghton Mifilin Company, 1963.

Catania, Charles A. Contemporary Research in Operant Behavior. Glenview, Illinols: Scott, Foresman and Company, 1968.

Chambers, Clarke A. Seedtime of Reform. Ann Arbor Paperbacks. Ann Arbor: The University of Michigan Press, 1963.

Clarke, Helen I. Principles and Practice of Social Work. New York: D. Appleton Century Co., Inc., 1947.

Cohen, Nathan Edward. Social Work in the American Tradition. New York: Holt, Rinehart and Winston, 1958.

Coleman, J. C. Abnormal Psychology and Modern Life. 2nd ed. Chicago: Scott, Foresman, 1956.

Coyle, Grace. "The Bridge Between Social Work and the Soclal Sclences," in The Soclal Welfare Forum 1958. New York: Columbia University Press, 1958.

- "Social Work at the Turn of the Decade." Proceedings of the National Conference of Soclal Work, 1940 p. 12 .

Dubos, Rene. "Second Edition: Does Man Have a Future." The Center Magazine, Vol. IV, No. 2 (1971) 
Evans, Richard I. B. F. Skinner: The Man and H1s Ideas. New York: E. P. Dutton \& Company, Inc., 1968.

Eysenck, H. J. Experiments in Behaviour Therapy. New York: The Macmilian Company, 1964.

"Therapies for Neurosis." New Society No. 358 (August 1969) 208-210.

Fraiberg, Selma. "Psychoanalysis and the Education of Caseworkers" in Ego-Oriented Casework: Problems and Perspectives. Edited by Howard J. Parad and Roger R. Miller. New York: Family Service Association of America, 1963.

Franks, Cyril M., ed. Behavior Therapy: Appraisal and Status. New York: McGraw-Hill Book Company, 1969.

Friedlander, Walter A. Concepts and Methods of Soclal Work. Englewood Cliffs, New Jersey: Prentice-Hall, Inc. - Introduction to Social Welfare. Englewood Cliffs, New Jersey: Prentice-Hall, Inc.

Fromm, Erich. Psychoanalysis and Religion. New Haven: Yale Undversity Press, 1950.

Germa1n, Carel. "Casework and Sclence: A Historical Encounter," in Theorles of Social Casework. Edited by Robert $W$. Roberts and Robert H. Nee. Chicago: The University of Chicago Press, 1970. pp. 3-32.

Goldste1n, Arnold P., Kenneth Heller, and Lee B. Sechrest. Psychotherapy and the Psychology of Behavior Change. New York: John Wiley, 1966.

Gordon, William E. "A Critique of the Working Definition." Soclal Work, Vol. 7, No. 4 (1962) 3-13.

- "Knowledge and Value: Their Distinction and Relationship in Clarifying Soclal Work Practice." Social Work. pp. 32-39.

Greenwood, Ernest. "Soclal Sclence and Soclal Work--A Theory of Their Relationship." Soclal Service Review Vol. XXIX (1955) 20-33. 
Grinker, Roy R., Helen MacGregor, Kate Selan, Annette Klein, and Janet Kohrman. "The Early Years of Psychiatric Soc1al Work." Social Service Review (1961) 35:111126.

Grossberg, John M. "Behavior Therapy: A Review." Psychological Bulletin, 62:2 (1964) 73-88.

Guthrie, E. R. "Association by Contiguity." Psychology: A Study of Science. Edited by S. Koch. Vol. II (1959) 158-195.

Halmos, P. The Falth of the Counsellors. New York: Schocken, 1966.

Hamilton, Gordon. "Psychoanalytically Oriented Casework and Its Relation to Psychotherapy." American Journal of Orthopsychiatry (1949) 19:209-219.

- Theory and Practice of Soclal Case Work. 2nd ed. revised. New York: Columbia University Press, 1951.

Hasan, S. Z. "Concepts and Methods in Soclal Work Research," in New Direction in Soclal Work. Edited by Cora Kasius. New York: Harper, 1954.

Hayes, Dorothy D. and Barbara K. Varley. "Impact of Soclal Work Education on Student's Values." Social Work Vol. 10 No. 3 (1965) 40-46.

Hilgard, E. R. Introduction to Psychology. 3rd ed. New York: Harcourt Brace and Company, 1962.

Holland, James G.and B. F. Skinner. The Analysis of Behavior. New York: McGraw-Hill Book Company, 1961.

Holl1s, Florence. ". . And What Shall we Teach? The Social Work Educator and Knowledge." Social Service Review, 42 (June 1968) 184-196.

- Casework, A Psychosocial Therapy. New York: Random House, 1965.

- "Contemporary Issues for Caseworkers." Smith College Studies in Social Work, Vol. XXX (February 1960) $157-174$. 
"The Psychosocial Approach to the Practice of Casework", in Theories of Social Casework. Edited by Robert $W$. Roberts and Robert H. Nee. Chicago: The University of Chicago Press, 1970, 33-76.

Jones, E. The Life and Work of Sigmund Freud, Vol. I. New York: Basic Books, 1953.

Kadushin, Alfred. "The Knowledge Base of Social Work," in Issues in American Soclal Work. Edited by Alfred Kahn. New York: Columbia UnIversity Press, 1959.

Kahn, Alfred J., ed. Issues in American Social Work, New York: Columbia University Press, 1959.

Kanfer, Frederick H. and George Saslow. "Behavioral Diagnosis," In Assessment and Status of Behavior Theraples and Associated Developments. Edited by Cyril Franks. New York: McGraw Hill Book Company, 1970.

Karchner, A., et. al "A Methodological Study of Freudian Theory." Journal of Nervous and Mental Diseases (October 1959), 129, 341-356.

Klenk, Robert $W$. and Robert M. Ryan, eds. The Practice of Social Work. Belmont, California: Wadsworth PublishIng Company, Inc.

Lee, Dorothy. Freedom and Culture. Englewood Cliffs, New Jersey: Prentice-Hall, Inc., 1959.

Lerner, Daniel, Ed. The Human Meaning of the Soclal Sclences. New York: Meridian Books, 1959.

London, Perry. Behavior Control. New York: Harper and Row 1969.

Lowry, Richard. The Elolution of Psychological Theory. New York: Aldine-Atherton, Inc., 1971.

Marmor, Judd. "Indications for Psychiatric Therapy or Social Casework." Soclal Casework (1955) 36:60-63.

- "Psychoanalytic Therapy as an Educational Process." Paper presented at Academy of Psychoanalysis, Chicago, May, 1961, in Psychoanalytic Education. Edited by J. H. Masserman. New York: Grune and Stratton, 1962. 
McIntire, Roger $W$. For Love of Children: Behavioral Psychology for Parents. Del Mar, California: CRM Books, 1970 .

Meyer, V. and Edward S. Chesser. Behavior Therapy in Clinical Psychlatry. New York: Science House, Inc., 1970.

Miles, Arthur P. American Soclal Work Theory: A Critique and a Proposal. New York: Harper and Brothers, 1954.

Miller, George A. Psychology The Science of Mental Life. New York: Harper and Row.

Millex, Neal. "Liberalization of Basic S-R Concepts: Extensions of Conflict Behavior, Motivation and Soclal Learning." Psychology: A Study of Sclence. Edited by S. Koch, II, 196-292. New York: McGraw-H111, 1959.

Mililkan, Max F. "Inquiry and Pollcy: The Relation of Knowledge to Action, "In The Human Meaning of the Social Sclences. Edited by Daniel Lerner. (1959) $158-182$.

Morrow, WIIllam R. and Harvey L. Gochros. "Misconceptions Regarding Behavior Modification." Social Service Rev1ew, Vol. 44 (September 1970), 293-307.

Noyes, A. P. and L. C. Kolb. Modern Clinical Psychlatry. 5th ed. Philadelphia: Saunder, 1958.

Parad, Howard J. and Roger R. Miller. Ego-Orlented Casework: Problems and Perspectives. New York: Famlly Service Association of America, 1963.

Parad, Howard J., ed. Ego Psychology and Dynamlc Casework. New York: Family Service Association of Amerlca, 1958.

Paul, Gordon. Insight vs. Desensitization: An Experiment In Anxiety Reduction. Stanford: Stanford University Press, 1966. - "Insight vs. Desensitization in Psychotherapy Two Years After Termination." Journal of Consulting Psychology, 31 (August 1967) 33-48. 
Perlman, Helen Harris. "Soclal Work Method: A Review of the Past Decade," in The Practice of Soclal Work. Edited by Robert W. Klenk and Robert M. Ryan. BeImont, California: Wadsworth Publishing Company, Inc., "The Problem-solving Model in Social Casework," in Theories of Social Casework. Edited by Robert W. Roberts and Robert H. Nee. Chicago: The University of Chicago Press, 1970, 129-180.

Pernell, Ruby B. "Soclal Work Values on the New Frontiers." Soclal Work Values in an Age of Discontent. Edited by Katherine A. Kendal1. New York: Counc1l on Social Work Ed., 1970.

Pollak, otto. "Exploring Collaboration Between Casework and Social Sclences in Practice." Soclal Work Journal, Vo1. XXXIII (October 1952), $177 \div 183$.

Pumphrey, Ralph E. and Murlel W. Pumphrey, eds. The Herltage of American Soclal Work. New York: Columbla University Press, 1961 .

Richmond, Mary E. Soclal Diagnosis. New York: Russell Sage Foundation, 1917 . - What is Soc1al Casework? New York: Russell Sage Foundation, 1922 .

Robinson, Virginia. A Changing Psychology in Social Case Work. Chapel Hill, North Carolina: University of North Carolina Press, 1930.

Salomon, Elizabeth L. "Humanistic Values and Soclal Casework." Social Casework, Vol. XIVIII, No. 1 (1967), $26-32$.

Schmidt, Herman O. and Charles P. Fonda. "The Reliability of Psychiatric Diagnosis: A New Look," in Research in Psychopathology. Edited by Herbert C. Quay. Princeton, New Jersey: D. Van Nostrand Company, 1963.

Simon, Bernece.K. "Social Casework Theory: An Overview," in Theorles of Social Casework. Edited by Robert W. Roberts and Robert H. Nee. Chicago: The University of Chicago Press, 1970, 353-394.

Simon, Justin. "Toward a Psychoanalytic Definition of Social Casework." Social Service Review, 36:1-12 (1962). 
Skinner, B, F. Sclence and Human Behav1our. New York: The Macmillan Company, 1953.

- Walden Two. New York: The Macmillan Company, 1948 .

Sloane, Bruce R. "The Converging Paths of Behavior Therapy and Psychotherapy." International Journal of Psychlatry, Vol. 7, No. 7 (1969), 493-503.

Smalley, Ruth E. "The Functional Approach to Casework Practice," in Theorles of Social Casework. Edited by Robert W. Roberts and Robert H. Nee. Ch1cago: The Un1versity of Ch1cago Press, 1970, 77-128.

Southard, E. E., M.D. and Mary C. Jarrett. The Kingdom of Ev11s. New York: The Macmillan Company, 1922.

Staats, A. W. and C. K. Staats. Complex Human Behavior. New York: Holt, Rinehart and WInston, 1963.

Stein, Herman. "Soclal Science in Social Work Practice and Education." Soclal Casework, Vol. XXXVI (Apr11 1955), 147-155.

"The Concept of Social Environment in Social Work Practice," in Ego-Orlented Casework: Problems and Perspectives. Edited by Howard J. Parad and Roger R. Miller. New York: Family Service Assoclation of America, 1963.

Sundberg, Norman D. and Leona E. Tyler. Clinical Psychology. New York: Appleton-Century-Crafts, 1962.

Thomas, Edwin J. "Behavioral Modiflcation and Casework," in Theorles of Soclal Casework. Edited by Robert W. Roberts and Robert H. Nee. Ch1cago: The Un1versity of Ch1cago Press, 1970, 181-218.

, ed. Behavioral Science for Social Workers. New York: The Free Press, 1967.

and Esther Goodman, eds. Socio-Behavioral Theory and Interpersonal Helping in Social Work. Ann Arbor, Michigan: Campus Publishers, 1965.

Thorpe, L. B. and B. Katz. The Psychology of Abnormal Behav1or: New York: Ronald, 1948. 
Truax, Charles B. "Reinforcement and Nonreinforcement in Rogerlan Psychotherapy." Journal of Abnormal Psychology, $71: 1$ (1966), 1-9.

- "Some Implications of Behavior Therapy for Psychotherapy " Journal of Counseling Psychology, Vol.

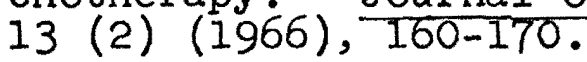

Ullmann, Leonard P. and Leonard Krasner. A Psychological Approach to Abnormal Behav1or. Englewood Cliffs, New Jersey: Prent1ce-Hall, Inc., 1969.

- Case Studies in Behavior Modification. New York: Holt, Rinehart and Winston, 1965.

Vance, Forrest L. "Methodology vs. Ideology in Psychologlcal Research." Journal of Counseling Psychology, Vol. 9 (Spring 1962), 12-17.

Valer, Barbu. "The Commonsense Psychtatry of Adolf Meyer." American Journal of Psychoanalysis, (1950), 71.

Varley, Barbara. "Soc1al Work Values: Changes in Value Commitments of Students from Admission to M.S.W. Graduation." Journal of Education for Social Work, Vol. 4, No. 2 (1968), 67-76.

Von Bertalanffy, Ludwig. Robots, Men and Minds. New York: George Braziller, 1967.

Wann, T. W., ed. Behaviorism and Phenomenology. Chicago: University of Chicago, 1964.

White, Clyde. "The Problems of Knowing in Soclal Work." Soclal Work, Vol. I (January. 1956), 94-99.

Wilensky, Harold I. and Charles N. Lebeaux. Industrial Society and Social Welfare. New York: The Free Press, 1958.

Winer, Frank. "Psychoanalyt1c Psychotherapy and Soclal Casework: Treatment of Choice." American Journal of Psychotherapy, 13:651-661 (1959).

Witte, Ernest F. "Student W1sdom and Values: The Positive Force of Disaffection." Social Work Values in an Age of Discontent. Edited by Katherine A. Kendall. New York: Council on Social Work Ed., 1970. 
Wolf, Eugene. "Learning Theory and Psychoanalys1s." International Journal of Psychlatry, Vol. 7 , No. 1 (1969), $525-535$.

Wolpe, Joseph. Psychotherapy by Reciprocal Inhibition. Stanford: Stanford University Press, 1958, 71.

and Arnold A. Lazarus. Behav1or Therapy Techniques. Oxford: Pergamon Press, 1966.

Yankelovich, Daniel and William Barret. Ego and Instinct: The Psychoanalytic View of Human Nature--Revised. New York: Random House, 1970.

Yates, Aubrey J. Behavior Therapy. New York: John Wiley and Sons, Inc., 1970.

"Symptoms and Symptom Substitution." Psycholog1cal-Review, Vol. 65 (1958), 371-374. 